\title{
Hubungan Kultur Darah Pasien Tersangka Sepsis dengan Nilai Prokalsitonin dan C-Reactive Protein
}

\author{
Bugis Mardina Lubis, Nelly, Beby Syofiani, Pertin Sianturi, Emil Azlin, Guslihan Dasa Tjipta \\ Departemen Ilmu kesehatan Anak Fakultas Kedokteran Universitas Sumatra Utara/RSUP H Adam \\ Malik, Medan
}

\begin{abstract}
Latar belakang. Diagnosis sepsis neonatorum sering sulit ditegakkan karena gejala klinis yang tidak spesifik pada neonatus sedangkan pemeriksaan kultur darah merupakan baku emas namun pemeriksaan tersebut hasilnya baru dapat diketahui setelah beberapa hari. Pada beberapa penelitian, nilai prokalsitonin akan meningkat saat sepsis sehingga sudah dikenal sebagai petanda infeksi pada penyakit berat

Tujuan. Mengetahui hubungan kultur darah dengan nilai prokalsitonin dan $C$-reactive protein pada pasien tersangka sepsis

Metode. Penelitian menggunakan studi potong lintang yang dilakukan di Divisi Neonatologi RS. H. Adam Malik Medan pada bulan Oktober 2011 - Februari 2012

Hasil. Didapatkan 43 bayi diperiksa kultur darahnya dan sebanyak 36 bayi terbukti postif (83.7\%). Terdapat hubungan yang bermakna antara hasil kultur darah dengan nilai prokalsitonin $(p<0,05)$ sedangkan dengan nilai CRP tidak terdapat hubungan.

Kesimpulan. Hasil kultur darah mempunyai hubungan dengan nilai prokalsitonin.

Sari Pediatri 2013;15(1):5-9.
\end{abstract}

Kata kunci: sepsis, neonatus, prokalsitonin, c-reactive protein

epsis merupakan respon inflamasi terhadap infeksi, pendapat lain menyebutkan sepsis neonatorum sebagai sindrom klinik penyakit sistemik yang disertai bakteremia yang terjadi pada bulan pertama kehidupan. ${ }^{1}$ Sepsis pada neonatus

\footnotetext{
Alamat korespondensi:

Dr. Bugis Mardina Lubis, Sp.A. Staf Divisi Neonatologi Departemen Ilmu Kesehatan Anak. FK-USU/RSUP. H. Adam Malik Medan. Jl. Bunga Lau No.17, Medan 20136. Tel.: 061-8365663. Fax. 061-8361721.

E-mail : bugismardina@yahoo.com
}

merupakan masalah yang belum dapat terpecahkan dalam pelayanan dan perawatan bayi baru lahir. ${ }^{2}$ Pada negara yang sedang berkembang, hampir sebagian besar bayi baru lahir yang dirawat mempunyai kaitan dengan masalah sepsis dan sampai saat ini sepsis pada neonatus masih merupakan penyebab utama mortalitas dan morbiditas pada bayi baru lahir. ${ }^{1,3}$

Angka kejadian sepsis di negara berkembang cukup tinggi, yaitu 1,8-18 per 1000 kelahiran hidup dengan angka kematian 12\%-68\% sedangkan di negara industri angka kejadian sepsis berkisar antara 3 per 
1000 kelahiran hidup dengan angka kematian 10,3\%. Berdasarkan perkiraan World Health Organization (WHO) terdapat 10 juta kematian neonatus setiap tahun dari 130 juta bayi yang lahir setiap tahunnya sedangkan di negara berkembang 10-50 kasus per 1000 kelahiran hidup. ${ }^{1,3}$

Berbagai macam kuman seperti bakteri, virus, parasit, atau jamur dapat menyebabkan infeksi. ${ }^{4}$ Pola kuman penyebab sepsis berbeda antar negara dan selalu berubah dari waktu ke waktu, bahkan di negara berkembang sendiri ditemukan perbedaan pola kuman, walaupun bakteri gram negatif rata-rata menjadi penyebab utama dari sepsis neonatorum..$^{5,6}$

Pemeriksaan penunjang yang sensitif dan spesifik diperlukan untuk menegakkan diagnosis sepsis pada neonatus secara cepat tanpa menunggu hasil kultur darah sehingga dapat memberikan terapi secara cepat dan tepat untuk mengurangi angka mortalitas dan morbiditas pada neonatus. ${ }^{10}$ Pemeriksaan $C$-reactive protein (CRP) tidak spesifik sebagai marker sepsis pada neonatus karena nilai CRP juga positif pada keadaan trauma. ${ }^{11}$

Prokalsitonin (PCT) adalah prekursor kalsitonin yang terdiri dari 116 asam amino yang disekresi oleh sel C dari kelenjar tiroid, pada keadaan normal kadar prokalsitonin meningkat pada kasus septikemia, meningitis, pneumonia, dan infeksi saluran kemih. ${ }^{10}$ Marker ini juga diproduksi oleh makrofag dan sel monosit pada beberapa kasus infeksi bakteri yang berat dan sepsis. ${ }^{12,13}$

Sejak awal tahun 1990-an prokalsitonin pertama kali digambarkan sebagai tanda spesifik infeksi bakteri. ${ }^{14}$ Kepekatan serum prokalsitonin meningkat saat inflamasi sistemik, khususnya infeksi bakteri. ${ }^{15}$ Prokalsitonin meningkat saat sepsis dan sudah dikenal sebagai petanda infeksi pada penyakit berat. ${ }^{16}$ Sampai saat ini masih dibutuhkan penelitian lebih lanjut tentang peran prokalsitonin ini terhadap kejadian sepsis pada neonatus. ${ }^{15-17}$

\section{Metode}

Penelitian potong lintang untuk melihat hubungan kultur darah dengan nilai prokalsitonin dan nilai $C$-reactive protein (CRP) pada pasien sangkaan sepsis di Unit Neonatologi RS Umum H. Adam Malik, Medan, periode Oktober 2011 - Februari 2012. Populasi penelitian adalah semua pasien bayi usia 0-28 hari dengan tersangka sepsis. Kriteria inklusi, yaitu bayi usia 0-28 hari yang diduga menderita sepsis dengan/tanpa melihat penyakit penyerta yang memenuhi salah satu gejala klinis (apnea, tachypnea, sianosis, muntah, diare, distensi abdominal, malas minum, hipotermia, hipertermia, hepatomegali, ikterik, hipoglikemia, hiperglikemia, letargi dan irritabilitas). Kriteria eksklusi adalah bayi yang telah mendapat pengobatan antibiotik selama $\geq 48 \mathrm{jam}$. Data primer diperoleh dari hasil pemeriksaan laboratorium darah rutin, CRP dan pemeriksaan prokalsitonin di Laboratorium Patologi Klinik RS Umum H.Adam Malik Medan. Pemeriksaan CRP kualitatif dilakukan secara manual dengan menambahkan partikel latex pada plasma pasien sehingga akan terjadi aglutinasi dengan nilai rujukan normal $<5 \mathrm{mg} / \mathrm{L}$. Prokalsitonin dikatakan positif apabila nilainya lebih dari $0,5 \mathrm{ng} / \mathrm{mL}$. Pemeriksaan kultur darah dilakukan di Laboratorium Mikrobiologi RS H Adam Malik. Sampel darah diambil dengan teknik aseptik dan dimasukkan ke dalam botol BACTEC kemudian dieramkan pada inkubator BACTEC dengan suhu $37^{\circ} \mathrm{C}$. Untuk isolasi kuman aerob, botol BACTEC yang menunjukkan adanya pertumbuhan kuman kemudian dilakukan pengecatan gram dan isolasi pada media blood agar dan Mc Conkey. Uji statistik dilakukan dengan SPSS menggunakan uji Chi-square dan bermakna apabila $p<0,05$.

\section{Hasil}

Didapatkan 43 pasien bayi dengan tersangka menderita sepsis secara klinis yang memenuhi kriteria inklusi penelitian dan 36 di antaranya terbukti kultur darah positif. Karakteristik sampel tertera pada Tabel 1. Karakteristik sampel penelitian berupa usia gestasi, jenis kelamin, berat badan lahir, dan diagnosis. Responden sebagian besar dengan usia gestasi 34 sampai 36 minggu, yaitu 16 (44\%) bayi. Jenis kelamin kedua kelompok mayoritas adalah laki-laki 19 orang dengan rentang berat bayi terbanyak 2500-3500 gram. Diagnosis terbanyak adalah distres pernapasan, 13 (36,1\%) bayi.

Tabel 2 menunjukkan tabel silang antara bayi yang mempunya kultur darah positif dengan nilai prokalsitonin. Tigapuluh lima (97\%) bayi yang terbukti sepsis mempunyai nilai prokalsitonin positif, dan $1(3 \%)$ bayi mempunyai nilai prokalsitonin positif dengan kultur darah negatif. 
Tabel 1. Karakteristik dasar

\begin{tabular}{|c|c|c|}
\hline \multirow[t]{3}{*}{ Karakteristik } & \multicolumn{2}{|c|}{ Kultur darah } \\
\hline & Positif & Negatif \\
\hline & $\mathrm{n}=36$ & $\mathrm{n}=7$ \\
\hline \multicolumn{3}{|c|}{ Usia gestasi, (minggu, n (\%)) } \\
\hline $26-28$ & $1(2)$ & $0(0)$ \\
\hline $28-30$ & $1(2)$ & $0(0)$ \\
\hline $30-32$ & $1(2)$ & $0(0)$ \\
\hline $32-34$ & $1(2)$ & $0(0)$ \\
\hline $34-36$ & $16(44)$ & $5(70,4)$ \\
\hline $36-38$ & $2(5)$ & $0(0)$ \\
\hline $38-40$ & $14(38)$ & $2(28,5)$ \\
\hline \multicolumn{3}{|l|}{ Jenis kelamin } \\
\hline Laki-laki & $19(52,7)$ & $4(57,1)$ \\
\hline Perempuan & $17(47,3)$ & $3(42,9)$ \\
\hline \multicolumn{3}{|l|}{ Berat badan lahir (gram) } \\
\hline$>1000$ & $1(2)$ & $0(0)$ \\
\hline $1000-2500$ & $7(19)$ & $2(28,5)$ \\
\hline $2500-3500$ & $27(75)$ & $5(70,4)$ \\
\hline$>3500$ & $1(2)$ & $0(0)$ \\
\hline \multicolumn{3}{|l|}{ Diagnosis } \\
\hline BBLSR & $4(11,1)$ & $2(28,5)$ \\
\hline BBLASR & $1(2,7)$ & $0(0)$ \\
\hline Distres pernapasan & $13(36,1)$ & $0(0)$ \\
\hline TTN & $4(11,1)$ & $2(28,5)$ \\
\hline Asfiksia neonatorum & $5(13,8)$ & $0(0)$ \\
\hline HIE & $4(11,1)$ & $0(0)$ \\
\hline Hirschprung diseases & $1(2,7)$ & $1(14,2)$ \\
\hline Atresia Ani & $2(5,5)$ & $0(0)$ \\
\hline Abses & $1(2,7)$ & $0(0)$ \\
\hline Meningocele & $0(0)$ & $1(14,2)$ \\
\hline ASD & $0(0)$ & $1(14,2)$ \\
\hline Hidrosefalus & $1(2,7)$ & $0(0)$ \\
\hline
\end{tabular}

Tabel 2. Tabel silang antara kultur darah dengan nilai prokalsitonin

\begin{tabular}{lcc}
\hline & \multicolumn{2}{c}{ Nilai prokalsitonin } \\
\cline { 2 - 3 } & Positif (\%) & Negatif (\%) \\
\hline Kultur darah & & \\
$\quad$ Positif & $35(97)$ & $1(14)$ \\
Negatif & $1(3)$ & $6(86)$ \\
\hline Total & 36 & 7 \\
\hline
\end{tabular}

Tabel 3. Tabel silang antara kultur darah dengan nilai C-reactive protein

\begin{tabular}{lcc}
\hline & \multicolumn{2}{c}{ Nilai CRP } \\
\cline { 2 - 3 } & Positif & Negatif \\
\hline Kultur darah & & \\
$\quad$ Positif & $24(85)$ & $12(80)$ \\
$\quad$ Negatif & $4(15)$ & $3(20)$ \\
\hline Total & 28 & 15 \\
\hline
\end{tabular}

Nilai prokalsitonin dan hasil kultur darah merupakan data yang tidak berpasangan, sehingga untuk melihat hubungan keduanya di uji dengan Pearson chi-square dengan hasil $\mathrm{p}=0,037$ karena nilai $\mathrm{p}<0,05$, maka disimpulkan bahwa terdapat hubungan antara nilai prokalsitonin dengan hasil kultur darah pada pasien sepsis neonatorum.

Tabel 3 menunjukkan tabel silang antara bayi berkultur darah positif dengan nilai CRP. Duapuluh empat $(85 \%)$ bayi yang terbukti sepsis mempunyai nilai CRP positif, dan 4 (15\%) bayi mempunyai nilai CRP positif dengan kultur darah negatif.

Nilai CRP dan hasil kultur darah merupakan data yang tidak berpasangan, sehingga untuk melihat hubungan keduanya di uji dengan Pearson chi-square dengan hasil $\mathrm{p}=0,177$. Disimpulkan bahwa tidak terdapat korelasi antara nilai CRP dengan hasil kultur darah pada pasien sepsis neonatorum.

\section{Pembahasan}

Angka kejadian sepsis neonatorum yang tinggi merupakan penyebab utama kematian pada neonatus. ${ }^{1}$ Kami mendapatkan 36 pasien yang mengalami sepsis bakterialis berdasarkan hasil kultur darah dari 43 bayi sebagai sampel penelitian. Usia gestasi bervariasi, terbanyak menderita sepsis bakterialis, yaitu usia gestasi 34-36 minggu 16 (44\%) bayi. Hal tersebut sesuai dengan teori bahwa faktor risiko yang dapat menyebabkan sepsis bakterialis, yaitu meliputi prematuritas karena bayi prematur memiliki berbagai masalah akibat organ tubuh yang belum berkembang, sehingga belum siap untuk berfungsi di luar rahim. Beberapa masalah yang dapat ditemui, antara lain masalah pernapasan, asupan, risiko perdarahan, dan infeksi. Bayi prematur memiliki risiko lebih tinggi untuk terjadinya sepsis neonatorum dibandingkan bayi aterm. ${ }^{4,6}$

Faktor risiko lainnya yang menyebabkan sepsis, yaitu berat lahir rendah, respiratory distress syndrom (RDS), dan tindakan resusitasi yang agresif. ${ }^{2}$ Riwayat asfiksia berat mempermudah terjadinya infeksi karena cedera sel akibat hipoksia dan akan memacu respon peradangan. ${ }^{2}$ Pada penelitian kami rentang berat badan lahir rata-rata bayi yang mengalami sepsis antara 2500-3500 gram. Faktor risiko lain yang juga memengaruhi terjadinya sepsis, yaitu jenis kelamin. Beberapa kepustakaan menyebutkan bahwa sepsis 
neonatorum lebih sering terjadi pada bayi laki-laki daripada perempuan, sesuai dengan penelitian kami yang menemukan 19 bayi laki-laki mengalami sepsis dibandingkan 17 bayi perempuan. ${ }^{2}$

Pada masa neonatal berbagai bentuk infeksi dapat terjadi pada bayi. Di negara yang sedang berkembang macam infeksi yang sering ditemukan berturut-turut infeksi saluran pernapasan akut, infeksi saluran cerna (diare), tetanus neonatorum, sepsis, dan meningitis. ${ }^{18}$ Diagnosis kerja terbanyak dijumpai pada pasien sepsis, dalam penelitian kami distres pernafasan 13 bayi, hal tersebut sesuai dengan penelitian yang dilakukan oleh Xavier, ${ }^{19}$ penyebab terbanyak sepsis berturutturut berasal dari infeksi saluran pernapasan (38\%), saluran cerna $(18 \%)$, infeksi pasca operasi $(9 \%)$, meningitis (6\%), infeksi saluran kencing (5\%), dan tidak teridentifikasi sebanyak (24\%).

Pola penyebab infeksi senantiasa berubah sejalan dengan kemajuan teknologi, demikian juga pola resistensi yang cenderung berubah sejalan dengan pemakaian antibiotik. Oleh karena itu, pengetahuan tentang pola penyebab, resistensi, dan faktor risiko perlu terus dipantau sebagai landasan dalam pemilihan antibiotik yang tepat bagi pasien bakteriemia khususnya pada neonatus. Untuk itu, masih perlu dilakukan penelitian tentang pola kuman dan sensitivitasnya terhadap antibiotik penyebab bakteremia secara berkala pada neonatus di Rumah Sakit Umum Pusat Haji Adam Malik, Medan.

Pemeriksaan kultur di RS H Adam Malik, Medan, butuh waktu beberapa hari untuk mendapatkan hasil sehingga diperlukan pemeriksaan lain yang cepat dan sensitif untuk mendeteksi sepsis pada bayi yang secara klinis dicurigai sepsis. Pada penelitian kami, diperoleh hasil bahwa pemeriksaan prokalsitonin mempunyai hubungan yang bermakna dengan hasil kultur darah apabila dibandingkan dengan nilai CRP sehingga dapat digunakan untuk melakukan evaluasi terapi sebelum hasil kultur diperoleh.

\section{Kesimpulan}

Sepsis pada neonatus merupakan penyebab utama mortalitas dan morbiditas pada neonatus. Baku emas untuk menegakkan diagnosis sepsis adalah kultur darah, tetapi membutuhkan waktu 3 sampai 5 hari, dan biaya yang tidak murah untuk memperoleh hasilnya sehingga terjadi keterlambatan pengobatan yang dapat memperburuk keadaan bayi, bahkan bisa menyebabkan kematian. Perlu suatu cara yang cepat dan tepat untuk menegakkan diagnosis dini sepsis bakterialis pada neonatus. Pada penelitian kami didapatkan bahwa prokalsitonin merupakan suatu cara yang cepat dan tepat untuk menegakkan diagnosis dini sepsis bakterialis pada neonatus karena mempunyai korelasi yang kuat dengan hasil kultur darah.

\section{Daftar pustaka}

1. Amirullah A. Sepsis pada bayi baru lahir. Dalam: Kasim SM, Yunanto A, Dewi R, Sarosa IG, Usman A, penyunting. Buku ajar neonatologi. Jakarta: Ikatan Dokter Anak Indonesia; 2008. h.170-87.

2. Gomella TL, Cuningham MD, Eyal FG, Zenk KE. Infectious disease. Dalam: Gomella TL, Cuningham MD, Eyal FG, Zenk KE, penyunting. Management, procedures, on-call problems, disease and drugs. New York: Mc Graw-Hill;2007.h.434-40.

3. Polin RA, Parravicini E, Regan JA, Taeusch HW. Bacterial sepsis and meningitis. Dalam: Taeusch HW, Ballard RA, Gleason CA, penyunting. Avery's diseases of the newborn. Edisi ke-8. Philadelphia; Elsevier Saunders;2005.h.551-600.

4. Klinger G, Levy I, Sirota L, Boyko V, Geva LL, Reichman B. outcome of early onset sepsis in neonatal cohort of very lowbirth weight infants. Pediatics 2010;125: e73640 .

5. Jackson GL, Engle WD, Sendelbach DM, Vedro DA, Josey S, Vinson J. Are complete blood cell count useful in the evaluation of asymptomatic neonates exposed to suspected chorioamnitis. Pediatrics 2004;113:117380.

6. Stoll BJ. Infections of the neonatal. Dalam: Behrman RE, Kiegman RM, Jenson HB, Stanton BF, penyunting. Nelson textbook of pediatrics. Edisi 18. Philadelphia: Saunders Company;2007. h.794-811.

7. Dear P. Infection in newborn. Dalam: Rennie JM, penyunting. Roberton's textbook of neonatology. Edisi ke-4. Elsevier Chrchill Livingstone; 2005. h.1011-91.

8. Bender L, thaarup J, Varming K, Krarup H, Eriksen SE, Ebbesen F. Early and late markers for detection of early onset neonatal sepsis. Dan Med Bull 2008;55:219-23.

9. Rodwell TE, Leslie AL, Tudehope DL. Early diagnosis of neonatal sepsis. J Pediatr 2008;112:761-7.

10. Balci C, Sungurtekin H, Gurses E, Sungurtekin U, 